\title{
On Henry de Bracton's on the Laws and Customs of England
}

\author{
Shiyi Guo* \\ Arcadia High School, Arcadia, California 91006, United States, Swendyy17@gmail.com
}

\begin{abstract}
This work aims to give a brief interpretation of the medieval social structure in England based on the legal work of Henry de Bracton, namely excerpts from On the Laws and Customs of England. Divisions that existed between the free and unfree, women and men, as well as power division between the English nobility and king were discussed from a legal perspective, including a brief summary of the excerpt translated into modern language.
\end{abstract}

Keywords: Henry de Bracton, Medieval England, English Law

\section{INTRODUCTION}

\subsection{Introduction to Henry de Bracton}

This thirteenth-century discourse on English law, known in Latin as De Legibus et Consuetudinibus Angliae, was penned by Henry de Bracton (Henricus de Brattona or Bractona, c. 1210-1268), an English royal judge and clergyman. While much remains unknown, it was speculated that he served as clerk to William of Raleigh, a medieval judge, and later promoted to the King's Bench in 1244 by Henry III of England and remained in the king's favor [1]. It is most likely that he was educated at Oxford before becoming an itinerant judge, which explains why his treatise included a combination of Roman and canon law commonly taught in universities [2]. His experience in religious teaching, with degrees in both civil and canon law at Oxford, also lent his treatise on English law a tint of deference to the Papal power [3]. As he is estimated to have outlived his sovereign, Henry III, and lived years after Edward I's accession, it can be assumed that he witnessed the signing of Magna Carta in 1215 and the burgeoning of conflict between barons and the kingship in England, which was reflected on his exploration of the topic in De Legibus et Consuetudinibus Angliae. Yet, he favored no political faction during his lifetime and "was noted for his ability to transcend such conflicts between king and baron.[4]". During his active service of the court, Henry de Bracton was known for his assiduity, recording nearly 2000 cases later organized in Bracton's Notebook. In the original treatise, it may be noted that Bracton, fortunate enough to obtain possession of a large number of rolls, cited some five hundred cases from the judicial record [5]. His expertise in law and first-hand experience with the court enabled a work as comprehensive as De Legibus et Consuetudinibus Angliae.

\subsection{Introduction to the Year 1235}

By 1235, two forms of law existed within England's realm, as rules lately established by authoritative act and rules conceived as established at time immemorial. This legal practice made it necessary for Bracton to distinguish, at the very beginning of his second volume, between the two codes. And, although the conception of the king being below the law was prevalent in medieval England, the law provided no direct means of compelling the king to redress his wrongdoings, as demonstrated by the first barons' war (1215-17) in which the barons resorted to force to restrain King John of England. The war, symbolizing a rising dispute between the king and the nobles, eventually secured the seal of Magna Carta in 1215, which may have influenced Bracton to claim certain concessions from the king to the nobles in his treatise [8]. For example, laws "cannot be nullified without [the nobles'] consent," as quoted from De Legibus et Consuetudinibus Angliae. In addition to secular affairs, the medieval tradition of taking biblical texts in the strictest sense had also casted influence on this treatise, in which biblical stories on God's wrath were taken word for word. Meanwhile, the legal text had also considered the actual historical phenomena of the time, which, namely, included the development of serfdom in the European world. The legal status of serfs after manumission, as well as the status of children born to enslaved parent or parents, were both addressed in great detail, corresponding with the matter of fact that bondage in the form of slavery had disappeared in 
England before the thirteenth century while serfdom flourished.

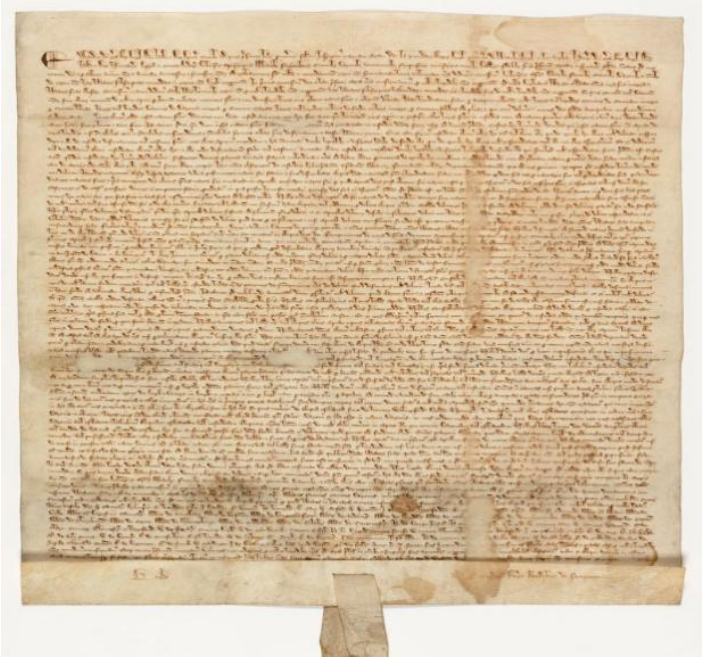

Figure 1 Magna Carta (1215)

\subsection{Introduction to the Document}

A king needs both law and arms to secure his rule. England uses both jus scriptum and unwritten law, both having the weight of authority, alongside with local customs that vary from place to place. This treatise consists of judicial records in the realm of England to instruct those unwise and unlearned judges to prevent injustice, as well as for general education, with the overarching purpose of preserving peace and justice.

With regards to law's execution, Bracton outlined that laws cannot be nullified without the nobles' consent, but may be changed for the better; if a difficult legal situation arises, let it be judged by a higher court since it is more advisable to seek counsel or have doubts than to determine rashly; lastly, similar cases can be judged based on precedents. In addition, judges must be wise and uncorrupted or else injustice will invite God's wrath.

With regards to law's definition, Bracton suggested the following relationships: 1) law is the restraint of offenses in relation to people, property, and actions, and were meant to be carried out as agreed by the republic; 2) justice proceeds from God, and thus interchangeable with law, which in its broadest sense may be seen as promoting virtue and prohibiting vice; 3) customs may replace law in some regions and carry equal authority; 4) jurisprudence is the combination of divine and human knowledge that distinguishes between the just and unjust, or the method to achieve justice; 5) whereas equity is uniformity and lies in human action (i.e. a judgement is equitable), justice lies in the mind (i.e. a man is just); 6) all rights arise from justice, or the unfailing will to give each person his or her right. The will, or the intent, thus distinguishes criminal from noncriminal acts.
Jus, the art of fairness, is derived from justice and has various usages. In this text it mostly means the virtue of harming no one and giving to each his or her right. The rights, concluded by Bracton, include proprietary right and possessory right. While one may have both, the proprietary right is held by the deceased one's nearest heir regardless of condition, and the possessory right may be held by other people, including the eldest brother, etc.

Rights are infinite, but laws are limited, only consisting of the public law, private law, natural law, jus gentium, and civil law. Public law pertains to the common welfare of the republic, providing men with priests and churches but also magistrates. Private law pertains to the individual welfare and is deduced partly from natural law, partly from jus gentium, and partly from civil law. Natural law, the most equitable law, is what God or nature taught all living things; that is, instinctive impulse that rational and irrational creatures alike share. Civil law is the custom, or it may refer to all the law used in a state regardless of it being natural law, civil law, or the jus gentium. The jus gentium refers to universal human law, including heterosexual marriage, childbirth and childrearing, obedience to parents and the state, and self-defense.

Further explanation on the jus gentium goes with the treatment of manumission: this act of giving formerly restricted liberty also comes from the jus gentium, joining the introduction of war for one's defense, establishment of kingdoms, and distinction between rights of ownership. The jus gentium is, generally speaking, the source of all contracts and distinctions.

Lastly, Bracton dealt in depth with the distinction between freedom and servitude: 1) freedom is the ability to do what one pleases unless forbidden by law or force, and since men are either wholly free or wholly bonded, by setting this distinction the civil law or the jus gentium differs from natural law; 2) servitude, an institution of the jus gentium, subjected one person to another; 3 ) while some practices of servitude are "conserving," meaning to preserve (rather than destroy) those in servitude, some may be called "serving," meaning the subject serves the one who subjugated him; 4) not everyone who serves is a serf, as demonstrated by those, albeit serving, reached prominence that differentiated them from the serfs.

Definitions aside, Bracton ascertained that bondsmen are either born unfree or made unfree. To be born unfree is to have an unfree parent or parents. The children follow the status of their mother, but once a free woman enters marriage with a villein, or gives birth in a villein tenement, the child is considered bond. Another exception is that if the neif is married to a freeman and gives birth in a free tenement, the child will also be considered free. Free men are made bond by capture, by acknowledging so in the king's court, or by ingratitude after manumission. The essential condition of bondsmen 
is the same. Men who are born free are freeborn. Free men are those manumitted from lawful bondage.

Very briefly, Bracton also touched on the topic of children: those born out of adultery, or those remarkably abnormal, are not considered as children, but those with small birth defects would be included.

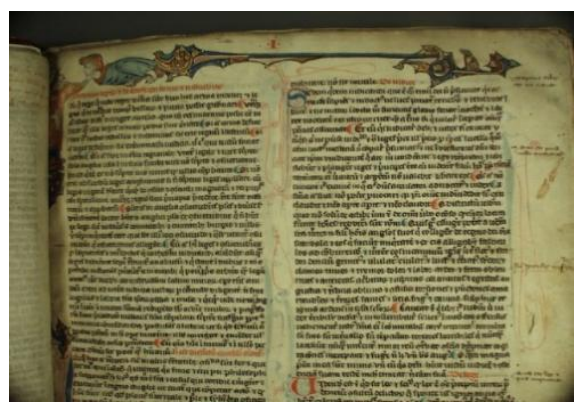

Figure 2 Bracton's De legibus et consuetudinibus Angliae. Manuscript on vellum, written about 1300

\section{TERMINOLOGY}

jus scriptum: written law

tractate: treatise

similibus ad similia: and such like

res publica: the state, republic, or commonwealth

jus: law; right (a power, privilege, faculty, or demand inherent in one person and incident upon another, or a capacity residing in one person of controlling, with the assent and assistance of the state, the actions of another)

lex: law

maleficia: wrongdoing

praetor: each of two ancient Roman magistrates ranking below consul

ars boni et aequi: art of the good and the fair (equitable)

sui juris: in one's own right

proprietas: ownership; property

seisin: possession of land by freehold

ad infinitum: again and again in the same way; forever

summum bonum: the highest good, especially as the ultimate goal according to which values and priorities are established in an ethical system praecepta iuris: not to harm anyone

villeinage: the tenure or status of a villein

villein: (in medieval England) a feudal tenant entirely subject to a lord or manor to whom he paid dues and services in return for land socage: a feudal tenure of land involving payment of rent or other nonmilitary service to a superior

demesne: land attached to a manor and retained for the owner's own use

statuliberi: slave (male) to which freedom has been promised subject to stated conditions

jus gentium: international law

neif: a female serf; a woman born in the state of villeinage

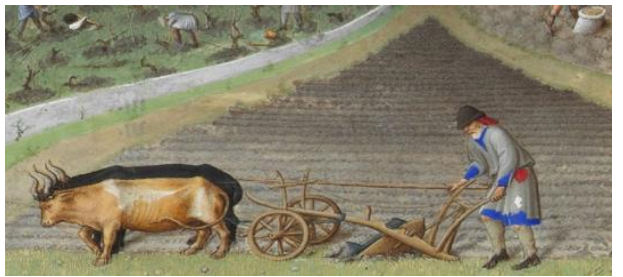

Figure 3 medieval peasant and farming

\section{CONCLUSION}

Clearly, one of the central divisions existing in Bracton's time was the division of men into free and unfree, and thus evolved different legal procedures and definitions as exact as to the birthplace and marriage status of the parents. We see that, with a large population confined to the manor of certain lords, classification of population naturally took the form of drawing boundaries between those in bondage and those who were not. Free and freeborn were also differentiated, along with the disparity between women and men with regards to manumission and status. The more important, however, was the illustration of legal principles that Bracton provided. Authority on law was not monarchical, since the legal process was largely seen as a collective business, and the English monarch's authority was not undivided, as the nobles shared the judicial authority - the nobility had to be consulted, for example, before the English king set his mind to change or nullify a law. Such dictation thus illustrated the post-Magna Carta England, a realm in which nobles shared, or competed with, the monarch's power rather than being merely servants of the state, promoted or relegated at the sole discretion of the king. This collective tradition was also bolstered by religious arguments that substantiated the reality of divided power, and the religiosity that had influenced Bracton's discussion manifested itself as the entire precept of justice was argued as "proceed[ed] from God" and "lies in the Creator [7]."

Another point to be noted here is the influence the feudal social structure of Bracton's time had casted on the English law. The social structure that rendered the economy largely dependent on agriculture had made land one of the most important forms of wealth, and, without explicitly stating so, Bracton had clearly outlined part of his law in terms of the people's relationship to the land 
as well as legal categorization of land unseen in our times. Whether it was about birth, as children born in a free tenement are more likely to be considered legally free than children who were born in a villein tenement, or discussions on property rights that stressed landed property, this emphasis helps encapsulate the medieval thought on land, confirming its crucial role in shaping legal understandings.

To summarize, the England that Bracton had in mind when he authored the treatise had a clear hierarchical structure. Again, those in bondage held observably less legal rights compared to those who were not. Calling it the "first and shortest classification of persons," Bracton had clearly perceived such distinction as one of the central features of his society, and based his treatise, first and foremost, on a guide to distinguish between "free [and] bond," since "all men are either free or bond [6]." In other words, there was to be no such thing as paredial serfage, or a middle course between the two. [5] Those in bondage were properties, only protected by criminal law in life and limb, and were especially disadvantaged in their legal relationship to their lords [10]. Other hierarchies were also present, most notably that between the genders. "Women differed from men in many respects," acknowledged by Bracton, because "their position is inferior to that of men [6]." While we may see this statement in terms of gender inequality, it may be more suitable to consider it in the context of social hierarchies, in which, just as the serfs held less legal rights than freemen, so did women when compared to men [9]. Grounded into a legal text, such hierarchies, both between the free and the unfree and between men and women, were sanctioned by law, which may also be perceived as Bracton's vision of his society. This conclusion was supported by Sir Frederick Pollock and Frederic William Maitland's work, which suggested that women in Bracton's time were excluded from public functions, including testifying in the court, "for the blood of a man shall not be tried by women," as asserted by Bracton himself. [5] In addition to the hierarchies governing the core of the population that necessarily spawned exclusion and deprivation of rights, the recognition given to the nobility's rights to share certain power with the monarchy also rendered insight into Bracton's view of the hierarchy at the top. Recognizing the present relationship between the nobility and the monarchy, Bracton then, as in 1235 , blended this acknowledgement into his law, nodding to the custom of limited monarchy by defining lawmaking as a collective business not to be ventured by the king alone.

\section{REFERENCES}

[1] Jones, Lauren Elizabeth. "King's Bench.” Legal Information Institute, Legal Information Institute, 4 Dec. 2019, www.law.cornell.edu/wex/king's_bench.
[2] "Henry de Bracton(c. 1210-1268)from On the Laws and Customs of England: Where a Man Commits Felony Upon His Own Person." The Ethics of Suicide Digital Archive, 21 Sept. 2015, ethicsofsuicide.lib.utah.edu/selections/bracton/.

[3] Moore, Thomas. The History of Devonshire from the Earliest Period to the Present. Illustrated ... by W. Deeble. Vol. 1-2. 1829.

[4] "Henrici De Bracton De Legibus Et Consuetudinibus Angliae Libri Quinque: in Varios Tractatus Distincti, Ad Diversorum \&amp; Vetustissimorum Codicum Collationem, Ingenti Cura Denuò Typis Vulgati." Henrici De Bracton De Legibus Et Consuetudinibus Angliae Libri Quinque: in Varios Tractatus Distincti, Ad Diversorum \&amp; Vetustissimorum Codicum Collationem, Ingenti Cura Denuò Typis Vulgati Wythepedia: The George Wythe Encyclopedia, lawlibrary.wm.edu/wythepedia/index.php/De_Legi bus_et_Consuetudinibus_Angliae.

[5] Pollock, Frederick. The History of English Law before the Time of Edward I. Liberty Fund, 2010.

[6] Bracton, Henry de, and George E. Woodbine. De Legibus Et Consuetudinibus Angliae. Yale University Press, 1940.

[7] Henry de Bracton, De Legibus Et Consuetudinibus Angliae, Cambridge: Published in association with the Selden Society [by] the Belknap Press of Harvard University Press, (1968), 23

[8] Bracton Online, Harvard Law School Library. https://amesfoundation.law.harvard.edu/Bracton/M anuscriptEdPage.htm.

[9] Fleming, Robin. Domesday Book and the Law: Society and Legal Custom in Early Medieval England. Cambridge University Press, 2003.

[10] Carpenter, Christine. "Law, Justice and Landowners in Late Medieval England." Law and History Review 1, no. 2 (1983): 205-37. doi:10.2307/743850. 